\title{
EFFECT OF MECHANICAL ACTIVATION COAL MINE OF KIYAKTINSKOYE YIELD OF LIQUID PRODUCTS
}

A.Zh. Bassarova, Orken, A.S. Kudabayeva, O.Ch. Abdrazzakov, M.I. Tulepov, A.A. Zhumabayeva

Established that the fine grinding of brown coal, lead to changes in its functional group composition, namely the reduction of carboxyl, carbonyl and aliphatic groups. Mechanical influences on coal simultaneously with a change in the total soluble fractions changed their composition and structure compared with the fractions of the original coal. Data obtained by hydrogenation show that the increased yield of liquid products by $10 \%$ and the depth of the transformation of the organic mass of coal by about 10-20\%. Lowering the temperature of the autoclave hydrogenation led to an increase in the degree of transformation of organic mass of coal at $10 \%$.

\section{КИЯҚТЫ КЕН ОРНЫНЫҢ КӨМІРІНІН МЕХАНИКАЛЫҚ АКТИВТЕНУІ СҰЙЫК ӨНІМДЕР ШЫҒУЫНА ӘСЕРІ}

\author{
А.Ж. Басарова, Өркен, А.С. Кудабаева, О.Ч. Абдразаков, М.И. Тулепов, А. А. Жумабаева
}

Қоңъыр көмірді ұнтақтау оның функционалды-топтық құрамын өзгертетіндігі, әсіресе карбоксил, карбонил және алифатты топтардың азаюын тудыратындывы анықталды. Көмірге механикалық әсер ету кезінде бастапқ̧ы көмірден алынган фракциялармен салыстырванда, ерігіш фракциялардың жалпь санының өзгеруімен қъатар, олардың құрамы мен құрылысы да өзгеріп отырадыл. Механикалық әсер битумдардың шысылмын көбейтумен құатар, газтәрізді компоненттер мен төменмолекулальққ сұйық құосыльсттардың генерациясын тудырады. Гидрогенизация кезінде алындан нәтижелер сұйық өнімдердің шысымы 10\% және көмірдің органикалық массасының айналу тереңдігі 10-20\% өсетіндігін көрсетеді. Гидрогенизаичя кезінде автоклавтавы температураны төмендету көмірдің органикалық массасының айналу тереңдігін $10 \%$ пайызzа арттырува мүмкіндік береді.

\section{УДК 541.13}

\section{ВАЖНЕЙШИЕ ИЗМЕНЕНИЯ В СИСТЕМЕ ХИМИЧЕСКОГО ОБРАЗОВАНИЯ В РК В ПОСТСОВЕТСКИЙ ПЕРИОД}

\author{
К. Бекишев
}

\section{Казахский национальный университет им. аль-Фараби}

В постсоветский период система образования Республики Казахстан находится в состоянии непрерывной модернизации и реформирования. Поэтапно были разработань несколько концеепий развития образования и приняты государственные программы на их основе [1-5]. Наиболее подробные сведения об их результатах, а также о состоянии системы образования и их анализ представлены в национальных докладах о состоянии и развитии образования, которые стали систематическими начиная с 2006 года, и обзорах [6-10]. Отметим наиболее важнейшие из них, имеющие отношения к химическому образованию.

\section{Среднее образование}

1. Единое национальное тестирование (ЕНТ). С 1999 года в Республике Казахстан для итоговой оценки учебных достижений учащихся применяется Единое Национальное Тестирование (ЕНТ), по результатам которого присуждают образовательные гранты для обучения в вузах [11]. ЕНТ проводится по четырем предметам: трем обязательным - казахский или русский язык (язык обучения), математика, история Казахстана и одному из предметов по выбору.

Сторонники ЕНТ считают, что преимуществом его является объективность, быстрота и устранение коррупции в вузах. Противники ЕНТ находят больше недостатков, чем преимуществ, однако замена до сих пор не найдена. Основным недостатком ЕНТ является то, что с его помощью трудно диагностировать глубину усвоения знаний и практически невозможно диагностировать степень освоения практических умений и навыков, не говоря уже об опыте творческой деятельности и эмоционально-ценностных отношений, которые в совокупности обеспечивают ключевые и предметные компетентности. Эксперты считают, что с помощью комплектов вопросов ЕНТ проверяются только в основном свойства памяти учащегося - уровень «узнавания» и «воспроизводства» знаний? 
Чаще всего критикуют качество заданий ЕНТ. Типичный комплект ЕНТ включает набор из 100 заданий закрытого типа с четырьмя вариантами ответов, из которых только один правильный. Так как не все ответы правдоподобные, учащиеся часто легко угадывают правильные ответы. К тому же количество вопросов слишком мало (25) для объективной оценки знаний учащихся. В целом, комплекты составлены так, что при желании сообразительные абитуриенты могут поступить на любую специальность, в том числе и на химические, не зная профильный предмет на достаточном уровне.

Конечно, постоянно ведется систематическая работа по улучшению качества комплекта и поиск альтернативных вариантов. Например, в «Программе развития образования до 2020 года» планируется «разработка новых систем оценки результатов общего образования школьников помимо EHТ, оценивающие способность учащегося к логическому анализу, культуру письменной речи, творческий потенциал поступающего, кругозор и оригинальность мышления».

На наш взгляд, более перспективным является «задачный подход», так как решение учебных задач моделирует решение личностью бытовых, технических, социальных и других проблем. К тому же расчетные и экспериментальные задачи, доли которых в учебном процессе пока крайне малы, позволили бы более точно диагностировать и оценить учебные достижения обучающихся и реализовать одновременно образовательные, воспитательные и развивающие функции обучения. Доказательством является, например, опыт химического факультета МГУ им. М.В.Ломоносова (Лунин В.В., Кузьменко Н.Е., Еремин В.В. и др.) [12 ].

В последнее время обсуждается изменение формата ЕНТ, т.е. увеличение числа предметов до шести и включение больше творческих заданий. В настоящее время к разработке контрольноизмерительных материалов привлечены зарубежные ученые- эксперты с мировыми именами.

Следует отметить, что число учащихся, выбирающих химию в качестве профильного предмета, с каждым годом уменьшается.

\section{2. Профильное обучение.}

В рамках осуществления реформы школьного образования Республики Казахстан в 10 -11 классах, начиная с 2006/07 учебного года, было введено профильное обучение[13]. Приняты два профильных направления: естественно-математическое и общественно-гуманитарное. Содержание каждого из них определяется Базисным учебным планом, а на его основе - типовыми учебными планами по направлениям обучения. На основе стандарта разработаны предметные программы по двум направлениям обучения. Для их учебно-методического обеспечения были созданы первые предметные учебно-методические комплексы (УМК), которые включают следующие компоненты: учебник, дидактические материалы, книга для чтения, рабочая тетрадь и методическое руководство для учителей. Основное внимание было уделено учебнику, который логично занимает центральное место в составе УМК.

К настоящему приняты много мер для улучшения качества учебников: созданы республиканский научно-практический центр (РНПЦ) «Учебник», государственная система экспертизы качества школьных учебников и некоторые другие. Система многоступенчатой экспертизы качества учебников включает: Департамент Министерства образования, РНПЦ «Учебник», Национальная академия образования и Республиканский совет по качеству учебников. В состав Совета привлечены известные педагоги, депутаты Парламента, члены Правительства, представители местных исполнительных органов.

Нерешенные проблемы: 1) трудно реализовать идеи профильного обучения в сельской местности; так как большинство школ являются малокомплектными; 2) несмотря на то, что существует общественно-гуманитарные (химия -1 час) и естественно-математические профили (химия -3 часа), выпускники сдают ЕНТ по одним и тем же комплектам вопросов; 3) элективные курсы по многим предметам (в том числе по химии) не обеспечены методически; 4) большинство школ не имеют материально-технической базы, необходимой и достаточной для реализации идей профильного обучения.

\section{3. Система работы с одаренными детьми.}

Понимая, что одаренные и талантливые дети являют собой интеллектуальный и творческий потенциал как основной ресурс развития государства в целом в РК осуществляется ряд мероприятий по выявлению, обучению и развитию одаренных детей на разных уровнях и в различных формах. Интенсификации работы с наиболее способными детьми и молодежью в Казахстане способствовало Распоряжение Президента «О государственной поддержке и развитии школ для одаренных детей» (1996 г.). Для его эффективной реализации в 1998 году был создан Республиканский научнопрактический центр (РНПЦ) «Дарын» («Одаренность») при Министерстве образования и науки, 
Основные цели и задачи РНПЦ «Дарын» были: содействие формированию интеллектуального потенциала Республики Казахстан; создание системы выявления, отбора, поддержки, развития и обучения одаренных детей; организация и проведение различных интеллектуальных соревнований и конкурсов. Структурой и деятельностью РНПЦ «Дарын» можно более подробно познакомиться в сайте www.daryn.kz и по публикациям научно-методического журнала «Дарын».

В республике в течение многих лет проводится многоуровневая республиканская олимпиада по 15 предметам, которая включает школьный, районный, областной и республиканский этапы. Их победители ежегодно участвуют на мировых и международных Менделеевских (бывшая Всесоюзная) олимпиадах по многим предметам, международных олимпиадах среди юниоров по естествознанию, а также на международной многопредметной олимпиаде «Туймаада» и на многих других. Набирается опыт и растет количество наград, завоеванных нашими учащимися на международных школьных предметных олимпиадах. Однако, к сожалению, основная идея проекта - использования талантливых детей на благо Родины не доводится до логического конца.

Сейчас начали реализовать новый проект - 20 интеллектуальных школ Первого Президента физико-математического и химико-биологического профилей. Миссией новых интеллектуальных школ является воспитание будущей научной элиты, высококвалифицированных менеджеров и управленцев во всех отраслях жизнедеятельности Казахстана.

4. Информатизация обучения.

В 1997 году была принята Госпрограмма информатизации системы среднего образования, в рамках которой к 2001 году все школы республики должны были обеспечены мультимедийными компьютерными классами, компьютерными учебными программами и электронными учебниками. К настоящему времени достигнуты определенные успехи [14], но не все проблемы решены. Так, например, пока не создан ни один электронный учебник по химии, соответствующий современным требованиям.

В рамках стратегических программ была разработана «Концепция создания и развития учебного телевидения в Республике Казахстан», так как эксперты считают, что учебное телевидение в условиях технического прогресса, развития цифровых медиа-технологий является перспективной формой образования, способной решить основную задачу современного образования: подготовку новой модели личности - образованной, креативной, умеющей самостоятельно принимать решение.

\section{Система высшего и послевузовского образования.}

Ниже рассмотрены только структуры, претерпевшие значительные изменения в последние годы или созданные впервые.

\section{1. Переход к трехуровневой системе.}

Казахстан определил ориентиры по вхождению в образовательное пространство Европы и осуществляет модернизацию образовательной деятельности в контексте европейских требований. Наша республика одним из первых на постсоветском пространстве в 1997 году подписала и ратифицировала Лиссабонскую Конвенцию по признанию квалификации, относящихся к высшему образованию в Европейском регионе.

В 2004 году Указом Президента РК была утверждена Государственная программа развития образования в Республике Казахстан на 2005-2010 годы. Одной из основных задач данной Программы являлось создание целостной трехступенчатой модели подготовки кадров, принятой в большинстве стран мира: «бакалавриат - магистратура - докторантура», где завершающим уровнем подготовки и научно - педагогических кадров высшей квалификации становится докторантура $\mathrm{PhD}$. К сегодняшнему дню практически все вузы Казахстана освоили первые две из этих ступеней. В двух ведущих университетах Казахстана (Казахский национальный университет им. аль-Фараби и Евразийский университет им. Л. Гумилева) уже осваивается и третья ступень - подготовка докторов философии.

Структура высшего и послевузовского профессионального образования включает бакалавриат, магистратуру и докторантуру (PhD) по формуле 4+2+3, образовательные программы которых взаимно согласованы с учетом принципа преемственности. В основе подготовки специалистов высшей квалификации используется кредитная технология обучения.

С 2006-2007 учебного года в РК действует новый классификатор специальностей. Изменилась структура и содержание стандарта подготовки бакалавров. Появился блок предметов по выбору, доля которого в структуре ТУП (РУП) постепенно растет. В рамках Болонского процесса обозначилась тенденция к изменению принципов представления в государственных стандартах содержания 
образования. Акцент переносится с процесса образования на измерение его результатов. Требования к результатам обучения формулируются в виде компетенций.

В 2010 году Казахстан официально присоединился к Болонской декларации и стал 47 участником Болонского процесса. Эксперты считают, что в условиях глобализации экономики, расширения международных отношений, возрастающей мобильности населения присоединение Казахстана к Болонскому процессу, считается, несомненно, правильным и своевременным.

Уже 17 лет существует Международная стипендия Президента РК «Болашак», которая присуждается наиболее талантливой молодежи для обучения в лучших зарубежных высших учебных заведениях по приоритетным для республики специальностям. Программа «Болашак» является очень эффективной, т.к. позволяет получить образование высокого качества в лучших университетах мира, полностью погружая в другую языковую среду, культуру народа, перенимая его лучшие традиции и нравственные ценности. Обучение по другим технологиям, методам, широкое участие в исследовательской работе университета в его современных лабораториях, позволяет нашим студентам получить профессиональное образование.

С 2011 года Концепция подготовки специалистов по программе «Болашак» изменилась. Если первые годы Казахстан готовил бакалавров за рубежом, теперь постепенно от подготовки бакалавров отходит. Если раньше они могли поехать за рубеж со школьной скамьи, то теперь он должны отучиться здесь 4 года, получить рекомендации, что имеют склонность к научным исследованиям и т.д.,

За эти годы казахстанские вузы накопили определенный опыт. К тому же теперь появился «Назарбаев Университет» в Астане, где созданы лучшие условия для подготовки специалистов очень высокого уровня.

\section{2. Система подготовки магистров и PhD.}

В Советском Союзе было две ученые степени - кандидаты наук и доктора наук. При этом они присуждалась не в результате специального обучения в вузе, как степень доктора философии на Западе, а только за счет подготовки и защиты диссертации, в вузах и в научно-исследовательских институтах, не связанных с системой высшего образования. Эта система продолжала действовать в постсоветский период и в суверенном Казахстане. Но, интегрируясь в мировое образовательное пространство и включаясь в Болонский процесс не логично оставить старую систему подготовки научных кадров.

Теперь в Казахстане создается новая система подготовка кадров высшей квалификации. Так, с этого года прекращена работа диссертационных советов в вузах, которые присваивали звания кандидатов и докторов наук. Теперь вместо кандидатов и докторов наук в Казахстане будет вестись подготовка магистров и докторов $\mathrm{PhD}$ или докторов по профилю.

Новая система отличается от старой тем, что она основана на органичном сочетании образовательной подготовки высокого уровня в соответствующем вузе и исследовательской программы. Следует отметить, что первого из этих компонентов при подготовке кандидатов и докторов наук фактически не было, и это главный фактор изменений. Для получения ученой степени доктора философии необходимо поступить в докторантуру вуза, в течение трех лет, как минимум, пройти соответствующее обучение, провести исследования, подготовить и защитить диссертацию. Докторанту дается возможность поработать в зарубежной лаборатории, для этого его работу курирует, помимо отечественного, еще и зарубежный руководитель. Это коренным образом отличает докторантуру от прежней аспирантуры, в которой, и это ни для кого не секрет, обучающийся все три года был предоставлен самому себе.

В соответствии с новым Законом «О науке» в Казахстане сформированы новые стимулы научного роста через ученые звания. Вводятся новые ученые звания ассоциированного профессора и профессора. На эти звания могут претендовать только штатные сотрудники научных организаций и вузов, работающие на полную ставку. Выработаны определенные требования для получения ученых званий. Наиболее важными среди них являются публикации в зарубежных рейтинговых изданиях, а также единолично написанные учебные пособия и монографии, и ряд других требований. Таких результатов невозможно достичь, работая по совместительству.

Теперь кандидаты наук, если они еще не получили звание доцента, могут претендовать на ученое звание ассоциированного профессора, а уже имеющие звание доцента, могут претендовать на ученое звание профессора. Если раньше звание профессора было чуть ли не «автоматическим приложением» к диплому доктора наук, то теперь ученые звания ассоциированного профессора и профессора повышают свой статус и становятся самостоятельными ступенями научной карьеры. 
По новым требованиям также надо выступать на международных (зарубежных) конференциях. С целью повышения качества ученых степеней и ученых званий теперь требуется публикации именно в рейтинговых журналах с высоким импакт-фактором.

Конечно, в соответствии с международными соглашениями в Казахстане будут признаны ученые степени, присужденные в других странах. Но процедура признания полностью основывается на сопоставлении государственного стандарта подготовки докторов философии в нашей стране с программой подготовки в той стране, где получена ученая степень. Особое внимание следует обратить на то обстоятельство, что по нашему государственному стандарту подготовка докторов философии проводится только очно, с отрывом от производства. То есть, нет заочной формы подготовки, нет соискательства. Поэтому процедуру признания ученой степени будут проходить только те лица, которые защитили кандидатские диссертации или получили ученую степень в других странах на основе обучения в очной аспирантуре или докторантуре.

Будут расширена подготовка магистров и докторов $\mathrm{PhD}$. Теперь будут готовить докторов $\mathrm{PhD}$ «точечно» - для тех предприятий, для тех научных направлений, которые для Казахстана являются приоритетными. Будут созданы более льготные условия для прохождения научными работниками государственных научных организаций стажировки в ведущих учебных заведениях, научных центрах и лабораториях.

Разрабатывается отраслевая программа и приглашение зарубежных ученых, выходцев из Казахстана, и «точечно» развивать те направления, которые необходимы сегодня в Казахстане, создавать вокруг них пояс молодых казахстанских ученых, которые в перспективе сами смогут это направление продвигать дальше.

\section{Заключение}

Таким образом, в постсоветский период система образования РК претерпела целый ряд существенных изменений. Она сейчас находится в транзитном состоянии, в стадии серьезной трансформации, реформирования и модернизации. Давать однозначную оценку уровня образования пока трудно. Требуется некоторый период, чтобы проводимая модернизация сказалась положительно на результатах системы образования. Хочется надеяться, что проводимые в стране реформы и модернизации образования приведут к существенному повышению качества образования в Республике Казахстан.

\section{Литература}

1. Государственная программа развития образования в Республике Казахстан на 2005-2010 гг. Утверждена Указом Президента Республики Казахстан от 11 октября 2004 года №1459.

2. Концепция развития образования Республики Казахстан до 2015 года. Одобрено Правительством Республики Казахстан (Протокол №3 от 24 февраля 2004 года).

3. Концепция развития образования Республики Казахстан до 2015 года. Одобрено Правительством Республики Казахстан (Протокол №3 от 24 февраля 2004 года).

4. Концепция государственной программы развития системы технического и профессионального образования в Республике Казахстан на 2008-2012 годы.

5. Государственная программа «Комплексная информатизация системы образования РК на 2007-2010 годы».

6. Дамитов Б.К., Ермеков Н.Т., Бекенова А.Б., Можаева О.И., Абсаматов А.У. Национальный доклад о состоянии и развития образования. - Астана: НЦОКО, 2006.

7. Дамитов Б.К., Ермеков Н.Т., Бекенова А.Б., Можаева О.И., Абсаматов А.У., Головатая Г.И., Габдуллина А. Национальный доклад о состоянии и развития образования. - Астана: НЦОКО, 2007.

8. Дамитов Б.К., Ермеков Н.Т., Бекенова А.Б., Бекиш Р.М., Можаева О.И., Головатая Г.И., Егимбаева Ж.К., Бондарь Л.А. Национальный доклад о состоянии и развития образования. - Астана: НЦОКО, 2008.

9. Дамитов Б.К., Ермеков Н.Т., Можаева О.И., Головатая Г.И., Егимбаева Ж.К., Ногайбаланова С.Ж., Сулейменова Ш.А., Махметова Г.П.. Текешева Т.У. Национальный доклад о состоянии и развития образования. - Астана: НЦОКО, 2009.- 308 с.

10. Каликова С.А., Рахимжанова Ж.Б., Агранович М.Л., Фрумин И.Д. Модернизация системы информационного обеспечения развития образования (включая образовательную статистику) в Республике Казахстан. // Аналитический доклад по заказу Всемирного банка. - Алматы, 2005.

11.http://www.testcenter.kz. Сайт Национального Центра Государственных Стандартов Образования и Тестирования.

12. Еремин В,В., Кузьменко Н.Е., Лунин В.В., Рыжова О.Н. Школьные химическое образование в России: стандарты, учебники, олимпиады, экзамены. // Российский химический журнал. - 2003. - T.XLVII. - №2. - C. 86-92. 
13. Концепция развития профильного обучения в Республике Казахстан.

14. Артыкбаева Е.В. Электронное обучение в общеобразовательной школе.-Алматы, 2010.-212 с.

15. «Создание и развитие учебного телевидения в Республике Казахстан» (Проект).- Астана, 2009.

16. Концепция развития послевузовского образования Республики Казахстан на 2010-2015 годы. Проект. - Астана, 2009.

17. Долгосрочная программа развития образования в РК до 2020 года.

\title{
ҚР-ДА ХИМИЯЛЫҚ БІЛІМ БЕРУ ЖУЙЕСІНДЕГІ КЕНЕСТІК ДӘУІРДЕН КЕЙІНГІ МАНЫЗДЫ ӨЗГЕРІСТЕР
}

\section{К. Бекишев}

Мақұалада тәуелсіздік жылдарында Қазақустан Республикасының білім саласында орын алван маңызды өзгерістер мен кейбір алда тұрван мәселелер құаралван.

\section{ВАЖНЕЙШИЕ ИЗМЕНЕНИЯ В СИСТЕМЕ ХИМИЧЕСКОГО ОБРАЗОВАНИЯ В РК В ПОСТСОВЕТСКИЙ ПЕРИОД}

\author{
К. Бекишев \\ В статье рассмотрены важнейшие изменения в системе образования Республики Казахстан в \\ постсоветский период и некоторые нерешенные проблемы.
}

\section{УДК 543.544}

\section{ЗӘРДЕГІ СТАНОЗОЛОЛДЫ СҰЙЫҚТЫҚТЫ ХРОМАТОГРАФИЯЛЫҚ ӘДІСПЕН АНЫКТАУ}

\author{
Г.А. Бексултанова ${ }^{1}$, А.К. Шаимова ${ }^{2}$ А.М. Шалдыбаева ${ }^{2}$, Т.Д. Талбаев ${ }^{1}$ \\ ${ }^{1}$ Спортшылардың допингке қарсы зертханасы, Алматы, Қазақстан, \\ əл-Фараби атындағы Қазақ ұлттық университеті, Алматы, Қазақстан, \\ e-mail: shaldybayeva@mail.ru
}

\begin{abstract}
Сұйықтықты хроматография масс-спектрометрия ддісімен адам агзасынан бөлінген зәрдегі метаболиттік өзгерістерге ұшыраган стероидты қосылыстар, соның ішінде станозолол зертелді. CX/MC/MC ддісі бойынша спортшылардың зәріндегі станозололдың сандық мөлшерін анықтау мүмкіншілігі көрсетілген.

Қазіргі заманда спортшылар арасында допингтік заттардың (тестостерон, оксандролон, станозолол т.б.) көп қолданылуына байланысты, бұл мақала спортшылар организміндегі станозололды сұйықтықты хроматография тандемдік масс-спектрометрия әдісімен анықтауға негізделген. Анаболикалық стероид станозолол ең алғаш рет 1959 жылы синтезделген. Халықаралық олимпиада комитетінің қолдануға тыйым салуына қарамастан, қазіргі кезде де спортта допинг ретінде пайдаланылады. Көптеген зерттеулер нәтижесінде адам зәрінің құрамынан станозолол мен

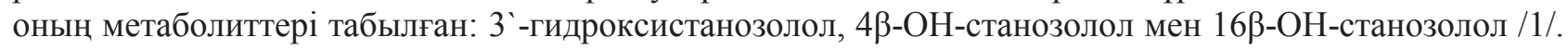

